\title{
Reality Counseling Approach in Understanding Homosexual Awareness
}

\author{
Alifa S. Rahmadhina* \\ Postgraduate Guidance and Counseling Program \\ Universitas Negeri Yogyakarta \\ Yogyakarta, Indonesia \\ alifasuri.2018@student.uny.ac.id*
}

\author{
Budi Astuti \\ Department of Educational and Guidance Psychology \\ Universitas Negeri Yogyakarta \\ Yogyakarta, Indonesia \\ Budi_astuti@uny.ac.id
}

\begin{abstract}
Homosexuality is a condition where male individuals or female individuals are attracted to the same sex. In Indonesia, this sexual disorder violates existing norms both legally and religiously. Some of the factors that make a person sexually impaired such as homosexuals are environmental influences that are unfavorable for the development of sexual maturity. This research is a literature study use a qualitative approach, which is an approach to understand behavior, perceptions, motivations, and other actions. Data obtained through interviewing two gay men aged 24 and 21 years. The reality approach in counseling uses techniques that aim to influence the counselee. A reality therapy approach is an approach that includes different therapies that all based on concepts and assumptions about humans.
\end{abstract}

Keywords - reality therapy, homosexual, gay

\section{INTRODUCTION}

Humans are living beings who are created in pairs it is intended to continue the descent. The sexual attraction is divided into two, where individuals who are paired with the opposite sex are declared heterosexual if individuals have same-sex partners called homosexuals who are usually divided into gays and lesbians in [1]

There are three parts of sexual orientation, namely 1) Heterosexual which is a sexual attraction towards different sexes. Women are attracted to men, and men are attracted to women. 2). Bisexual is a sexual attraction to women and men at the same time. 3). Homosexuality which is a sexual attraction of the same sex. Women are attracted to women who are referred to as lesbians. Men are attracted to men which ia referred to as gays statement according to [2].

The terms homosexual (lesbian and gay), bisexual and transsexualism are in UU No. 18 Year 2014. Homosexuals are sexually attracted to members of their gender groups as stated [3]. Whereas homosexuals are attracted to people of the same sex. It can be concluded that homosexuality is a state of feeling statements that initially causes a person to have a lust for the same type. Besides, there is a desire for harmony to dominate his desires in the sexual sphere in [4].

And according to [5] in Indonesia, homosexuality is something that violates the norms of religious and state law. Around 1968, the term wadam (Female Adam) emerged as a more positive term to replace words for feminine male transvestites or homosexuals. In 1969, the first wadam organization, the Djakarta wadam Association (HIWAD) was facilitated by the Governor of Jakarta, Ali Sadikin. Then in 1985, a gay group in Yogyakarta established the
Yogyakarta Gay Fraternity $(P G Y)$ with the publication of Jaka magazine. On August 1, 1987, the Lesbian and Gay Archipelago Working Group.

GAYA NUSANTARA (GN) was formed in Pasuruan, Surabaya, which was the successor to Lambda Indonesia. The community published magazines and book series from 1988. There is also the Yogyakarta Gay Community which developed into the Gay Indonesian Society (IGS).

In Indonesia, LGBT people sought legal loopholes to strengthen their existence as social communities [6]. For LGBT people, liking the same sex is a natural will from God. Besides, under the pretext that LGBT is a Human Rights (HAM). They continue to demand the government of the Republic of Indonesia, to recognize, promote, fulfill, and protect the rights of its citizens and to punish every violator of rights under international human rights law.

The Criminal Code was made by the Dutch East Indies government which is still valid today, as a basis for court. Articles of the Criminal Code that involve sexual matters, are articles 281-289, 292-294, 297-299, 389, 534, and 535. From the description of the Criminal Code (KUHP) article 292, some conclusions can be drawn concerning homosexual behavior, including (1) the law governing sexual crimes in Indonesia, does not give primary attention to homosexual behavior. Homosexual behavior can only be punished if it is done with an immature person. (2) this Article does not only apply to homosexuals but also to other sexual behavior that is carried out with minors [7].

Today, more and more people are openly expressing their sexual orientation and demanding their rights. Owing to the performance of the perpetrators and their supporters, acceptance of LGBT rights throughout the world has increased. The governments of several countries in Europe have begun to enact laws that accept LGBT and antidiscrimination laws, such as the Netherlands, France, Denmark, and the United Kingdom. In Indonesia, the Indonesian Ulama Council also issued Fatwa No. 57 on December 31, 2014, which stated that being lesbian or gay, was involved in sodomy, rape, and homosexual relations and relationships between heterosexuals that were not legitimized through religious marriage were considered unlawful and punishable [8].

Based on early research 2017 conducted said that the supporting factors of people becoming homosexual are wrong parenting in the family, the absence of a role model to imitate the quality of male personality, as well as an incorrect understanding of sexuality [9]. Two things cause a person to be gay as mentioned namely, hereditary factors or genes and environmental factors [10]. 
This reinforced in social learning theories that do not specifically emphasize childhood experiences. However, it is underline sexual experiences for the first time until the child reaches orgasm, which usually at puberty and adolescence. It is a critical factor for determining one's sexual orientation. The learning process that takes place after the first experience will play an enormous role in the development of deviant sexual fantasies. Thus, it becomes a habit of masturbation or the formation of other abnormal sexual behavior. It turns out the fantasies are a very strong stimulant value for determining one's sexual behavior [11].

The orientation of sex education aims to explain the ethics of channeling sexual needs properly. Thus, it does not fall prey to acts of sexual deviation. Sex education is not only limited to the introduction of anatomy, physiology, venereal disease, and deviant sexual behavior. However, sex education means much more to shapes the emotional maturity of children and attitudes in response to their sexual instincts [12].

The failure to achieve developmental tasks in the aspect of gender identity awareness can be seen from confusion related to the gender identity and ignorance of the concepts of masculinity and femininity. The condition of individuals who have confusion over their gender identity is commonly referred to as gender identity disorder, this phenomenon is better known as transgender [13]. To overcome the related problems can be given reality therapy.

Reality therapy is a form of cognitive behavioral therapy developed by Dr. William Glasser, a psychiatrist, in 1965. As stated 2005, it is a form of behavior modification because in institutional applications it is a type of operative conditioning that is not strict whose success in translating several behavioral modification concepts into practice models which are relatively simple and straightforward [14].

\section{METHODS}

The type of data used is secondary data. Data collection methods used are literature study and early research results. This research is a literature study with a qualitative approach, which is an approach to understanding behavior, perceptions, motivations, and other actions [15]. Afterward, the data obtained is compiled, analyzed, and concluded to get conclusions about the study of literature based on the realistic approach to homosexual awareness.

\section{RESULT AND DISCUSSION}

\section{Result}

Homosexuality in Indonesia is unacceptable and still afraid to show its existence. If people are aware of its existence, it will clash with religious norms and human rights $(H A M)$. Human rights restrictions allow the existence of human rights. Therefore, it is also present in the implementation of these restrictions to the interest of many people. Human rights should not be used as a front to help other people or public interest [14]. The results of previous studies showed that homosexuality is a problem in the samesex sexual attraction of an individual because naturally, humans should have an interest in the opposite sex. The cause of being homosexual can be caused by internal and external factors.

This is in line with the results of an interview with two gay people. A gay with initials AU stated that it is usually caused by experience or trauma from childhood or when dating someone. According to $\mathrm{AU}$, someone become gay from a lifestyle that wants to be experimented with. From the results of these trials, AU made money from the gay lover and this cause addiction. To conclude, it made AU continue to choose to be gay when beforehand was a heterosexual. Another interview with the man whose initials are RG that came from a broken home family. RG had a single mother figure as his role model. He takes abusive actions against him who has imperfections in his 3 fingers. This makes him not confident in his social environment. As a result of his lack of confidence, RG also has a cousin who assisted in supervising and paying attention to RG from a young age. $R G$ cousin was a gay person who quite existed in the city of Yogyakarta. When the RG was asked why he had a sexual attraction with the same type, he only replied that he was not confident if he wanted to be close to women and was afraid if he was too close to a woman.

\section{Discussion}

Basically, the homosexual problem is not new in Indonesia. Homosexuality is a problem, that it may encourage counselors to help client correcting the wrong thing. For homosexual problems, Reality therapy approach may apply to help homosexuality problems approach. Reality therapy is a form of behavior modification in its institutional applications, which is a type of operative conditioning that is not strict. A reason Glasser gained popularity was his success in translating several behavioral modification concepts into a relatively simple and straightforward model of practice. There are two basic psychological needs.

First, the need to love and be loved and second, the need to feel that we are valuable to ourselves and others [7]. Helping individuals fulfill both needs is the basis of reality therapy, counselors act as: (1). Motivator, who drives the counselee, (2). Channels of responsibility, (3). Moralist, (4). Teacher, (5). A binding contract (contractor). Reality therapy is a system that is focused on current behavior [16]. That therapy functions as a teacher and model and confronts clients in ways that help clients face reality and meet basic needs without harming themselves or others said [10]. In this reality therapy, it can help clients in meeting the biological needs of individuals including feelings of love and being loved also to feel valued and useful to others [17].

Based on research showed the results that reality therapy is effective in increasing self-regulated learning for underachiever students. Thus, it is clear that reality therapy is not based on a deterministic philosophy about humans, but is built on the assumption that humans are selfdetermining agents. This principle implies that the consequences of his own behavior. Apparently, people become what they have set. For homosexual issues, it is expected that the provision of reality therapy can slightly change their perspective and build awareness in themselves related to sexual attraction. Even though Glasser states that humans are free to choose two things in themselves, which are choosing how to think and how to act [18].

\section{CONCLUSION}

From the conclusions of the literature study, the authors provide advice especially for people who experience sexual 
disorders (homosexuals) should consult with psychologists, psychiatrists, and religious leaders to be given appropriate therapies and directions. Other than that, trying to stay away from the environment that can influence to become a homosexual. Parents are expected to be more sensitive to the behavior of their children if there is deviant behavior. Therefore, the children did not become a person with sexual deviations.

Several factors can cause a person to experience sexual disorders such as homosexuality, which are environmental influences that are not good or unfavorable for the development of sexual maturity. Besides, it is also someone who is looking for sexual relationship satisfaction. Homosexuals are more vulnerable to deviant behavior, criminal acts and even become one of the spreaders of diseases such as HIV/AIDS. However, not a few homosexuals who have dared to explore himself in the environment to expose thereal identity of being homosexual.

\section{ACKNOWLEDGMENT}

The author would like to thank the interviewee who provided the authenticity of the response for the sake of writing the article. The most important thing is for the parents of the researchers and would like to thank all the parties involved. Criticisms and suggestions given are very helpful in this writing.

\section{REFERENCES}

[1] Sarwono, Sarlito W. (2010). Psikologi Remaja Edisi Revisi. Jakarta: PT Raja Grafindo Persada.

[2] Ratri, E. Mastuti, Rachmad, D.Winarno dan Lita, W. Hastuti. (2012). Pembentukan Identitas Seksual Pada Remaja Gay. Kajian Ilmiah Psikologi 2(1) Juli - Desember 2012, hal. 194 - 197
[3] Sobur, A (2016). Kamus Psikologi. Bandung: CV Pustaka Se.tia.

[4] Kamus Besar Bahasa Indonesia. (Online).Tersedia di https://kbbi.kemdikbud.go.id/entri/homosek sual diakses 03 Oktober 2019.

[5] Muthmainnah, Y. (2016, March). LGBT Human Rights in Indonesian Policies. 4(1).

[6] Triawan, A. d. (2008). Jadi, kau Tak Merasa Bersalah: Studi Kasus Diskriminasi dan Kekerasan Terhadap LGBT. Jakarta: Citra Grafika.

[7] Sibli, N. "Larangan Homoseksual Dalam Pasal 292 KUHP dan PAsal 494 RUU-KUHP Ditinjau dari Hukum Pidana Islam” Lex et Societatis, V (6) August 2017.

[8] Komisi Fatwa Majelis Ulama Indonesia. Tersedia di http://lampung.kemenag.go.id di akses 05 Oktober 2019.

[9] Gallo, A. Y. D dan Endang, S. I. (2017). Pengalaman Menjadi Gay. Jurnal Empati, Agustus 2017,7 (3), Halaman 116-126.

[10] Saleh, G dan Arif, M. (2017). Rekayasa Sosial Dalam Fenomena Save LGBT. Jurnal Komunikasi Global, 6 (2), 2017.

[11] Kartono, K. (2009). Psikologi Abnormal dan Abnormalitas Seksual. Bandung: Mandar Maju.

[12] Ilham, L. (2019). Pendidikan Seksual Perspektif Islam dan Prevensi Perilaku Homoseksual. Jurnal Peradaban dan Pemikiran Islam. 3(1) Juni 2019.

[13] Rio, H. (2017). Peran Bimbingan Konseling Dalam Komunitas LGBT Prosiding Seminar Nasional Peran Bimbingan dan Konseling dalam Penguatan Pendidikan Karakter Universitas Ahmad Dahlan 2017.

[14]Corey, G. (2005). Konseling \& Psikoterapi Teori Dan Praktek. Bandung : Refika Aditama.

[15] Husain, Usman dan Soetady. (2000). Metodologi Penelitian Sosial. Jakarta: PT.Bumi Aksara.

[16] Singgah, D. Gunarsah. (2000). Konseling Dan Psikoterapi. Jakarta: Gunung Mulia.

[17]Corey, G. (1999). Teori \& Praktek Konseling dan Psikoterapi, Bandung: PT. Rafika Aditama.

[18] Suri, M. Siregar dan Wiwik, S. (2013). Efektifitas Terapi Realitas Untuk Meningkatkan Selfregulated Learning Pada Mahasiswa Underachiever. 5 (2), Desember 2013 halaman 80-85. 